\title{
Interdisciplinarity in Pastoral Theology. An Example of Socio-theological Research
}

\author{
WIOLETTA SZYMCZAK \\ The John Paul II Catholic University of Lublin \\ wioletsz@kul.pl, ORCID: 0000-0002-8749-8862
}

\begin{abstract}
The purpose of the article is to analyze the idea of interdisciplinary research involving pastoral theology and sociology. This is one of the methodological proposals for research projects carried out under pastoral theology. Interdisciplinarity is understood as combining research methods for the cooperation of scientists from both disciplines in the process of planning, implementing and interpreting the results of empirical research. It is inspired by a problem identified in pastoral theology that requires exploration. The presentation consists of three parts. The first is devoted to the location of empirical research within pastoral theology. The second concerns the assumptions and significance of interdisciplinary research involving pastoral theologians and sociologists. In the final part, the areas of interdisciplinary cooperation among the research teams are pointed out. The potential of qualitative research as a space for cooperation among representatives of both sciences and as an important source of knowledge from the viewpoint of pastoral theology is shown. The comparative and synthetic method was used. The analysis shows that interdisciplinary research in the field of pastoral theology has great potential related to the acquisition and interpretation of multi-faceted empirical data and the designation of new research fields, which will significantly enrich the theological analysis process as well as the presentation and application of pastoral models.
\end{abstract}

Keywords: interdisciplinary research, pastoral theology, sociology, qualitative research methods

One of the contemporary challenges of pastoral theology is researching the context in which the Church operates and proclaims its saving mission. Pastoral theology deals with questions concerning and the need for systematic empirical research that supports the process of understanding the changes affecting the Church's activity as the People of God functioning in the world and fulfilling its mission. ${ }^{1}$ The ecclesiological understanding of pastoral theology, taking into account the sociological aspect, represented, among others, by Karl Rahner, Ferdinand Klostermann, Norbert Greinacher, Rolf Zerfass, and in sociology by François Houtart, Joseph Laloux, Władysław Piwowarski, draws attention to the theological nature of this subdiscipline and its formal subject, which is making the Church a community in present times. ${ }^{2}$

Kamiński, “Teologia pastoralna. Istota i zadania," 12.

In the definition that takes into account the sociological element, Władysław Piwowarski ("Perspektywa teologiczna," 32, 33) defines it as "a science which, through theological and sociological analysis of 
Pastoral theology is characterized by an existential and pragmatic orientation. It is also a normative science, creating sets of norms, principles, and theological models "which the Church, religious communities and their representatives should be guided by in various areas of ecclesial activity. The normative and practical aspects of scientific knowledge," as Ryszard Kamiński states, "constitute a coherent whole in pastoral theology. It is impossible to construct principles and models of ecclesial activity without prior scientific reflection on the reality and foundations of its evaluation." 3

The above postulates implicite include the need to take into account research in the field of non-theological sciences, in particular the social sciences. However, there are reservations that pastoral theology cannot be content with the results of this type of research alone. ${ }^{4}$ The detailed suggestions aim at seeking and formulating a theological interpretation of these results, assuming that every event in the world is God's voice speaking to the Church. In this context, researching the field of social sciences is to support the process in which theological criteria are applied at the stage of formulating problems, and then the obtained data are analyzed. ${ }^{5}$

Theologically reading the results of empirical research in the 1960s was subject to criticism. According to Józef Mikołajec, it was not fully known how to conduct a theological reflection on data from the empirical sciences. It was even stated that there was "an almost invincible difficulty in connecting two types of perception of the same reality in a compatible manner." In this context, interdisciplinary research was initiated as a parallel dialogue between interacting disciplines. ${ }^{7}$

Regardless of this, the postulate of theological reflection on the results of social science research is still being formulated and implemented. Philip Hughes sees this methodological path as one of the important ways in which pastoral theology can obtain and interpret data about culture. In his opinion, the study of culture should not be determined by the theological approach to it. Concerning adequate theologi-

the specific present situation of the Church, aims to develop current theological models and the corresponding imperatives and action programs, according to which the Church in this specific, present situation updates its essence, fulfilling the mission of redemptive mediation"; idem, "Eklezjologiczna koncepcja," 300-309.

3 Kamiński, "Normatywny i praktyczny wymiar," 325; idem, “Teologia pastoralna," 838-847.

4 In general, two paradigms are pointed out regarding the use of the results of empirical research in the field of secular sciences in pastoral theology; the first, by Joseph Cardijn, is reduced to the triad "see, evaluate, act," and the second, by Grazioso Ceriani, is expressed in the form of a practical syllogism, in which "the premises of the greater are provided by theology, and the premises of the lesser by sociology or psychology; the conclusion is of a theological character because of the greater premise"; W. Przygoda, "Model pastoralny," 516.

5 Kamiński, "Normatywny i praktyczny wymiar," 328-330; Johannes Först analyzes in detail this type and the place of empirical research in the field of social sciences in pastoral theology: J. Först, Empirische Religionsforchung, 47-61.

6 Mikołajec, "Problem metody," 27.

7 Mikołajec, "Problem metody," 28. 
cal references to culture and social life, theology faces the task of reacting to culture as it is perceived from the viewpoint of the social sciences. Hughes also believes that the implementation of interdisciplinary research is burdened with the risk of errors related to, for example, the ignorance of sociological concepts and methods by theologians, or the risk of sociologists not taking into account the issues of faith and religion important from the perspective of human existence. ${ }^{8}$

August Laumer, in turn, writes about various justifications for using analyzes of the present moment within the framework of pastoral theology conducted in the framework of the humanities. In this context, he refers to the argument of effectiveness, but also to the theological interpretation of reality mentioned above as a space for God's action, which refers to Karl Rahner's theology, and later to the Second Vatican Council. Comprehending it and providing an answer are the Church's tasks. Laumer shows doubts regarding the practical aspects of pastoral theology's interest in knowledge from the humanities. It is related to the issue of selectivity in the area of the choice of disciplines, and within them the scope of theories, methods and data that pastoral theology wants to use, the reception of unexpected or opposing empirical research results. For example, this means the theological vision of reality, and in the opposite direction, equally treating pastoral theology in interdisciplinary dialogue. Laumer states that interdisciplinary dialogue, in order to be adequate and properly constituted, should be formed based on the equal rights of sciences. ${ }^{9}$

Against this background, the idea of interdisciplinarity appears as one of the methodological possibilities, yet it requires arrangements and precisely clarifying its understanding and scope. This is especially the case in specific situations and research institutions aimed at acquiring an up-to-date view of reality, as indicated, among others, by the document of the International Theological Commission of 2012: Theology Today. Perspectives, Principles and Criteria. ${ }^{10}$ The concept of interdisciplinary research is, therefore, noteworthy from the perspective of pastoral theology, interpreted and discussed (especially in the sphere of German theology) as a practical science, and from the meanders of modern times, marked by a fast-paced lifestyle and complex changes.

Knowing that there are scientists who consider pastoral theology to be a practical science, attributing it the traits of an empirical science, the text starts from the position that pastoral theology as having its tools for the empirical study of socio-cultural reality and social aspects of the Church's saving activity. It uses the achievements and methods of social sciences, including sociology (as well as the sociology of religion). Sociology has a well-established, long-standing tradition of studying the social life,

\footnotetext{
Hughes, "Theology and Social Sciences," 43, 52-54.

Laumer, "Pastoraltheologie," 153-154.

Międzynarodowa Komisja Teologiczna, Teologia dzisiaj, 51-53.
} 
its transformations and conditions, including religiosity and the interaction between society and religion. ${ }^{11}$

As Kamiński emphasizes, thanks to the research carried out by sociologists of religion, pastoralists have a chance to recognize and assess the contemporary pastoral situation with high probability, ${ }^{12}$ which does not change the need for constantly questioning the adequacy of the research, reliability and accuracy of analyzes serving to discern various aspects and problems in social life. Concerning the interaction among these disciplines, two paths are indicated: pastoral theology needs research in the field of sociology, designed and implemented as autonomous research projects, or projects in the field of topics and methods that meet the questions and problems raised by pastoral theologians.

Assuming the differences in these two approaches, it is worth noting that the second, pointing to the legitimacy of creating interdisciplinary projects, creates the possibility of posing questions and conceptualizing research problems focused on learning about and analyzing reality from points of view important for theological reflection and pastoral practice, taking into account the Church's praxis. In this context, Mikołajec's statement is correct: "although pastoral theology is based on the unchanging premises of Revelation, it is not a timeless science, and it is not even trans-spatial," ${ }^{13}$ which results in the topicality and complexity of its research methods.

When pointing to the critical nature of the scientific reflection carried out within pastoral theology, it is worth repeating that the results of empirical research in the field of selected social sciences, in perceiving their analysis and then the theological interpretation, are to support the Church in fulfilling its mission. "An essential task of pastoral theology is to enable the Church to respond adequately to the problems of the contemporary world, and not to preserve the existing forms of Church life. To this end, pastoral theology must critically reflect on the activities of the Church in the world." ${ }^{14}$ This analysis is a type of kairos, at the same time referring to the messages and results of scientific reflections. It should be done in the light of theological criteria and result in action imperatives that show what in a specific place and time must be done for the Church's good, according to its essence and having discerned God's purpose. ${ }^{15}$

The above-mentioned premises prompt us to focus on interdisciplinarity within empirical research, which is part of the paradigm of pastoral theology. The goal of

11 This is regardless of empirical research designed and carried out independently by pastoral theologians using a previously acquired sociology workshop.

12 Kamiński, Wprowadzenie do teologii pastoralnej, 27-29.

13 Mikołajec, "Problem metody," 25.

14 Mikołajec, "Problem metody," 31.

15 Kamiński, Wprowadzenie do teologii pastoralnej, 25; cf. also: Haslinger, "Die wissenschaftstheoretische Frage nach der Praxis," 102-122. 
the text is to show the specificity and importance of interdisciplinary research combining pastoral theology and sociology. It aims to explore methodological proposals which, corresponding to the assumptions formulated in pastoral theology, will indicate the potential of interdisciplinary projects, while maintaining the identity and autonomy of each discipline.

Such research fulfills the condition of relevance in the process of responding to the signs of the times; it meets the need for methodologically correct, substantively saturated and up-to-date empirical research. The following analyzes are legitimate due to the practical dimension of pastoral theology and its reference to the methodology of selected secular sciences. They are also to show the importance of sociological imagination in interdisciplinary research, which, as Piotr Sztompka writes, "is the ability to link what is happening in society with the diversity of structural conditions and activities carried out by causative subjects. As a result, a really complex, complicated and varied mosaic of social life emerges."16

The issues discussed in the article, apart from topicality in terms of meta-subject issues, are significantly related to the current socio-cultural situation at the local and global dimensions. Contemporary times, with postmodernist tendencies and pluralist world-views, are characterized by an unprecedented pace of civilization changes. These involve societies, economies, cultures, religions and the religiosity of individuals and societies, including phenomena encompassing the entire global village. Their characteristic feature is the uncertainty inherent in the freedom and independence of choices, interpenetration, mutual generation and conditioning of the above-mentioned processes, the coexistence of opposite and extreme phenomena. As sociologist Maria Libiszowska-Żółtkowska aptly points out, the world of religious beliefs, when faced with different views and religious traditions, through the unlimited availability of information and publications in the area of traditional and new religions, is exposed to the process of the relativization of religious attitudes.

One's world of religious beliefs ceases to be self-evident, and "requires self-confirmation, reassurance in one's reasons. A reality open to multiplicity, enabling the coexistence of this diversity, makes a person individually responsible for his own choices. The free market creates possibilities, shows opportunities, suggests and tempts people with competitive offers. However, it does not provide ready-made, homogenous recipes. Everyone makes their individual choice on their own and takes a risk." ${ }^{17}$ The outlined context requires theologians and pastors deeper and constant, competent observation and reflection distanced from informational noise. At the same time, pastoral theology is to help them make decisions supporting every positive process in

16 Sztompka, Socjologia, 48.

17 Libiszowska-Żółtkowska, "Przedmowa," 15. 
the context of implementing the Church's mission, but also anticipate problems and efficiently search for solutions to new difficulties. ${ }^{18}$

\section{Empirical and Interdisciplinary Research in Pastoral Theology}

The sensitivity of contemporary assignments in pastoral theology is associated with increasing difficulties in adjusting the activities of the Church "to the turbulent and multidirectional changes in the world." ${ }^{19}$ Kamiński raises the need for ever greater "adequate scientific research concerning the increasing challenges of these times." ${ }^{20}$ He locates the problem within the general postulate of placing theological and pastoral analyzes in the area defined in the search for the synthesis of pastoral theory and practice. These are the normative and practical dimensions, including a comprehensive approach to the above-mentioned research, focused on the synthesis and taking into account mutually implicating factors within the first and the second dimensions of pastoral theology.

Church theory is understood as a set of normative statements directly arising from Christ's words and deeds, practiced as the official activity of the Church and performed by persons holding offices, as well as Church activities for all members of the Church. ${ }^{21}$ The emphasis on synthesis results from the growth of people's critical approach to Church practice and theory, starting with the processes of secularization that mark contemporary societies and including the interaction of pastoral theology with the praxeological sciences. In other words, it is a holistic approach covering the doctrinal and pastoral dimensions of the Church's life striving for complementarity among these, which Kamiński states is missing. ${ }^{22}$

In response to the question of why this is so, one can point to the problem of the discrepancy between doctrine and practice, which simplifies a doctrine, limits it, makes it incomprehensible, etc. If this thesis were true, we ought to analyze the process of implementing the perspectives: to what degree, scope and why is a doctrine not reflected in the Church's praxis? At what point does this process break down or disrupt? Correct and accurate implementation requires, in accordance with the prac-

18 Its subject, according to Wiesław Przygoda ("Paradygmaty metodologiczne," 32-33), is "the existence and salvific activity of the Church under current conditions. This subject covers the supernatural and natural life of the people of the Church, ad intra and ad extra ecclesial activity, the pastoral tasks of the hierarchy, consecrated persons and the laity. All this is what pastoral theology wants to grasp, critically evaluate and express systematically, taking into account the current conditions in which the universal Church or the local Church achieved its assignment in the world".

19 Kamiński, "Normatywny i praktyczny wymiar," 331.

20 Kamiński, "Normatywny i praktyczny wymiar," 331.

21 Kamiński, "Normatywny i praktyczny wymiar," 321.

22 Kamiński, "Normatywny i praktyczny wymiar," 323. 
tical syllogism in the paradigm of pastoral theology, ${ }^{23}$ inter alia, discerning the reality in which a person lives. Such discernment takes into account the theological interpretation of man's existence on earth, but also a possibly multi-level, scientific description of this existence, which is the reality a Christian struggles with on his path to salvation. At the same time, this concerns, as John Paul II stresses in his apostolic exhortation Pastores Dabo Vobis, "evangelical discernment of the socio-cultural and ecclesial situation in which the particular pastoral action has to be carried out."24

Subordinated to the search for the truth about culture, pastoral theology uses empirical data to help accurately formulate pastoral postulates implemented in this particular reality, at the same time relating to the transcendent reality having a theological character. This process requires a great deal of sensitivity, acuteness, research courage and methodological precision, relating both to the scientific dialogue with empiricism and the moment of applying its results in pastoral practice at the level of content, structure, and the language of pastoral models.

In this context, various variants of referring pastoral theology to empirical research carried out within the framework of non-theological sciences can be analyzed, including the option of interdisciplinary research. Norbert Greinacher presents the concept of interdisciplinarity as a dialectical connection of the three components of pastoral theology into one process: analysis of the current situation, the "case of Jesus," meaning the history of God's revelation expressed in Jesus Christ, and pragmatics, meaning normative indications. In interdisciplinary research, the current situation, divine revelation and its influence in history up to the present day, and pragmatics generate questions for each other and demand answers. ${ }^{25}$

Greinacher concludes that "pastoral theology is not only supposed to answer questions asked by people today, but should also pose questions to contemporary people, investigate reality, thought structures and credibility in today's social system of values." ${ }^{26}$ This means that it applies empirical and normative methods, combining deductive and inductive methods. These suggestions draw attention to scientists practicing pastoral theology and sociology, whose cooperation crystallizes the shape of interdisciplinary research. Thus, the idea of interdisciplinarity means using techniques and research tools in the field of social sciences in research programs carried out within pastoral theology and scientific cooperation in the framework of parallel and dialectical dialogue throughout the research process.

The proposal of interdisciplinary research assumes their servile role concerning the goals of pastoral theology and placing them at the level of a minor premise, the concept of a practical syllogism in which the greater premise and conclusions are

\footnotetext{
23 Przygoda, "Model pastoralny," 516.

24 John Paul II, Exhortation Pastores dabo vobis, 57.

25 Greinacher, "Teologia praktyczna," 67.

26 Greinacher, "Teologia praktyczna, 71.
} 
of a theological nature. Such research aims to support the process of properly recognizing the reality in which the Church carries out its mission in order to formulate the most adequate one in a salvific perspective, and to implement it in contemporary realities of imperatives and pastoral models. Their accuracy, effectiveness and a satisfactory manner of implementing them by Catholics, communities and organizations of the Church, will depend, inter alia, on the acquired empirical knowledge and its correct perception, meaning the degree of understanding culture in a given place and time.

Analyzing the situation in which the Church currently carries out is mission takes place in a specific place and time, which is one of its key factors, because social changes are occurring one after another and generate new phenomena at a previously unthinkable pace. Due to pastoral practice, a consciously sustained sensitivity to the changing social context is needed, while being permanently rooted in the unchanging Truth of Revelation and the tradition of the Church. An equally important challenge is the dialectical process of the three elements of practical theology reading and interacting with each other. ${ }^{27}$

In the context of the current socio-cultural situation, it is necessary to emphasize the importance of vigilance and inquisitiveness in the perception of reality and interest in the real, dynamically and comprehensively decoded situation in which man lives. According to the programmatic encyclical by John Paul II, Redemptor Hominis, "[man] is the primary and fundamental way for the Church, the way traced out by Christ himself, the way that leads invariably through the mystery of the Incarnation and the Redemption." 28 Pastoral theology is obliged to people and communities living here and now, the participants in this very historical moment, which has its beginning and end, and is at the same time the space and time of their faith journey, striving for salvation together with the community of the Church.

The defined subjective and temporal sensitization, raised in the postulate of responding to the signs of the times that is essential for pastoral theology, ${ }^{29}$ appears to be one of the key premises in the area of the Church's pastoral activity and the meta-subject of scientific reflection on it. Interdisciplinarity fits this postulate as a path supporting its implementation, and sociology, with its instruments and empirical orientation, offers in this dimension the potential for efficient operationalization of problems identified in social reality and its reliable translation into the language of further research procedures. In turn, the subject of pastoral theology has a dynamic and is immersed in the context. The interests of pastoral theologians include the pursuit of reliable knowledge for the adequate development of principles and directives supporting the Church in the mission of redemptive mediation. Wiesław Przygo-

\footnotetext{
Mikołajec, "Problem metody," 28.

John Paul II, Encyclical Redemptor Hominis, 14.

Zuhlener, Pastoraltheologie; Szymczak, "Znaki czasu," 467-469.
} 
da emphasizes that this dynamic nature of the subject of pastoral theology requires using many strictly defined research methods, including cooperation with theological and non-theological scientific disciplines. ${ }^{30}$

\section{Pastoral Theology and Sociology. Assumptions of Interdisciplinary Research}

Sociology, with its descriptive orientation and already developed methodological background, meets the above-described requirements of pastoral theology in its individual paradigms. Due to its focus on describing the social reality, when identifying social phenomena, problems and processes, sociology takes into account the multidimensionality of social situations, the multifaceted nature of a given phenomenon, its contextual nature and conditions. Thanks to its instrumentation and sociological imagination, it allows us to see the phenomenon in its social and cultural context, presented from an external viewpoint and available through the prism of various paradigms and methodologies. It is interested in an individual's place in the social world: the groups in which one functions, the processes and systems one creates together with others, the interactions one participates in and the conditions of these phenomena and processes. ${ }^{31}$

The sociological view of social phenomena, particularly embedded in the paradigm of sociology that aims to understand, means a constant striving to analyze the situation of an individual in their social and cultural context from the perspective of axio-normative systems and social changes. The sociological imagination takes into account the subjectivity and agency of the individual, questions about his or her situation and the place of personal and social happiness. This concerns whether the individual, as Paul Prüfer writes, finds happiness "in individualistic isolation or social openness and altruism? Does fulfillment and attaining one's desires take place in creative and effortlessly efficient action, based on difficult choices and undertaken effort in individual searching? Or perhaps it is in the peaceful submission to the determination of forces coming from the outside?" 32 These are questions with which pastoral theology, seeking the truth about the current context of the Church's saving mission, constantly faces and repeats.

Sociology successfully develops the area outlined by these questions, and this applies, inter alia, to the sociology of religion, which by definition studies the interplay of societies and religions. According to Janusz Marianski, the sociology of

Przygoda, "Paradygmaty metodologiczne," 33.

Sztompka, Socjologia; Giddens, Socjologia; Jabłoński, “Od filozofii społecznej," 21-44.

Prüfer, "Czy nauka społeczna," 32. 
religion deals with "the empirical and scientific explanation of the mutual relations between religiosity and society. Its foundations are the religious dimension of society and the social dimension of religion (...). Sociology studies how religious factors penetrate the process of creating society, the role religion plays in the constitution of social groups, and the influence religious values and norms exert on people's behavior and their interpretation of everyday life." 33

From the viewpoints and analyzes of sociologists, religion constitutes a social and cultural fact, both constituting an independent variable that affects society and culture, and a dependent variable, a reality subjected to the influence of phenomena and processes with their civilization, its cultural, local and global changes. Sociology responds to social processes observed in the world, including those revealing religions and changes in religiosity, by trying to capture and study them, often using new research questions and tools. ${ }^{34}$

The empirical orientation of sociologists and their sensitivity to fluctuations, change, the interdependence of social processes and changes in the field of religion, may constitute a significant potential for pastoral theology. They can bring sensitivity and clarity to the perception of social reality, at a certain stage turning off the filter in the form of a normative attitude. At the semantic level, whether at the time of defining problems or research questions or data analysis, they can correct the perception and accurate description of reality in various directions. Cooperation among representatives of both disciplines may, therefore, be fruitful in different directions.

One thing would be to consciously incorporate the perspective of pastoral theology into the process of identifying a problem perceived by the sociological eye, meritorically interesting for theologians. Yet, another thing is the operationalization of the problem noticed and reported by theologians, in a language and concepts enabling empirical research and empirical access to a selected fragment of reality thanks to correctly selected and applied sociological methods and techniques. These are examples of forms and levels of interdisciplinary activities and complementary cooperation that preserve the autonomy of disciplines.

Sociology focuses on analysis and leads to the inner depths of the social world. As such, it always offers pastoral theology paths and tools aimed at getting to know the realities in which people and communities belonging to the Church live their faith. It also means openness and striving to explore knowledge that is so far unknown or aspect-oriented at the stage of surprising conclusions, because, for example, it violates the functioning interpretation scheme or the current perception of reality, taking into account even a smaller number of independent variables. A research project boldly connecting the questions by theologians and sociologists can help in identifying and explaining the factors generating or conditioning a given social prob- 
lem, as well as the circumstances favorable and hindering the implementation of pastoral models. This requires the readiness to question the existing patterns, meaning the way of thinking about praxis, the paths of implementing the indications resulting from divine revelation.

Assuming different tasks and the specifics of each of the sciences, several points of contact can be identified in the pastoral and sociological approach to the analysis of social reality as the context of the Church's saving activity. The first is the perspective of the person, the subject and author of actions on the individual and social dimensions. This is characteristic of sociology that tries to understand things, more often emphasized and explained by sociologists in the context of aspirations for the most accurate and comprehensive understanding of social reality. ${ }^{35}$ This goal cannot be achieved without taking into account the acting subject, its intentionality and agency, and at the same time being anchored in a world full of life shaped by culture.

Here, we are talking about the concept of a reflective and rational subject, who makes decisions voluntarily, interprets a given experience, creates a social world by interacting with others. ${ }^{36}$ They are the actions of a person comprising a dynamic process and interaction, also shaped by previous experiences. ${ }^{37}$ In pastoral theology, the emphasis is on the ecclesial character of the Church's pastoral activity, but with the awareness that striving for salvation is a person's path, and this takes place in the Church community. Discerning the situation of a man's history, with his subjectivity and agency, the social and cultural context of his functioning, as well as these determinants on the micro and macrosocial scale, including the perspective of his temporal and eternal vocation that is to be achieved, is part of the core paradigms of pastoral theology using methods in the field of sociology. ${ }^{38}$

The second plane that delineates the common problem areas of pastoral theology and sociology is the moment of "seeing" inscribed in the paradigm of pastoral theology in the already mentioned practical syllogism, located on the level of a minor premise, assuming a comprehensive reading of reality. The stage of methodological proceedings, referred to as "seeing," means getting to know the situation of the contemporary world on a global and local dimension, including various aspects of the existence of individuals and communities and their conditions, and the issues of Church adaptation and effectiveness under these circumstances. Adequacy concerns specific people, families, groups, social groups and communities recognizing their current situation and its determinants. Adventure emphasizes that at the level of "seeing," also referred to as the stage of diagnosis (in Josef Müller's paradigm, the three steps are: diagnosis, reflection, action), it is necessary to take into account

\footnotetext{
35 Blumer, Interakcjonizm symboliczny, 99-108.

36 Piotrowski, Ład interakcji, 133-134.

37 Ziółkowski, Znaczenie, interakcja, rozumienie, 101-103.

38 Haslinger, Pastoraltheologie, 34-98; 231-288; Zuhlener, Pastoraltheologie.
} 
the spiritual aspect of reality and its saving interpretation. ${ }^{39}$ For sociologists, this means broadening the explored issues to include new aspects among the analyzed issues, as well as, for example, supplementing or updating the language used to formulate questions to respondents, prepare data analyses and finally research reports.

In some areas, the subject of empirical research, meaning issues raised within the framework of pastoral theology and sociology, is also common. The interests of both sciences include the activities of religious institutions: the Church, religious organizations, issues concerning their organizational culture, changes in religiosity and emanations of its new forms, issues concerning education, changes in the function of religion on a social scale, changes in the perception of religion and the Church in public life, changes in language channels and forms of transmitting religious contents, religious and moral attitudes and determinants of their changes.

Summarizing this part of our considerations, it should be stated that interdisciplinary research can be conducted without violating the principle of the primacy of theological questions over sociological or other questions from the area of secular sciences. For pastoral theology, an analysis made by empirical sciences is not sufficient if the assumption is made that every situation for man, society, and the Church functioning in it has a theological dimension and is interpreted as God's call to the Church..$^{40}$ In this context, interdisciplinary projects have the advantage, since they respect the autonomy of the sciences and take into account the above principle. They broaden the scope of theoretical analyzes carried out and may have a stimulating or modifying influence on the Church's pastoral practice. It is therefore an argument favoring a polite and fruitful dialogue between both disciplines. It also indirectly points to another important requirement for this type of research: namely, humility and the awareness of functioning in a process that is a research project in stages, but also in a changing reality.

This attitude implies a constantly updated cognitive curiosity about the sphere of social facts, important from the perspective of the normative profile for pastoral theology. A dialogue using the results of empirical sciences will facilitate the process of specifying and transposing official content into a language that is understandable, but also saturated with proper argumentation, standards and models. Pastoral reflection should implicitly assume an adequate use of the obtained results of interdisciplinary research, the courage to accept unexpected data or indicate, for example, weak points in practice, an awareness that at least in the horizontal aspects of earthly life, to the extent specified by research projects, they answer the question: "what is going on?"

Another argument supports the value of interdisciplinary studies. The pastoral ideal expressed by the Magisterium of the Church should not be treated as the only

39 Przygoda, "Paradygmaty metodologiczne," 34.

40 Kamiński, "Normatywny i praktyczny wymiar," 330. 
point of reference on the formal level, which shows and creates pastoral models, because it offers the possibility of repeating on the practical level indications, the language and theses from the level of official documents. Such a procedure will stop the aforementioned process of translatability at the level of general normative postulates remaining, however, at a considerable distance from the praxis indicated by Kamiński. This will happen when pastoral reflection does not entail the hardships of a comprehensive interpretation and adequate implementation of the obtained data.

Interdisciplinary research has the potential to support pastoral theology in identifying and explaining the signs of the times and current cultural changes, in recognizing and analyzing the process of translating theory into pastoral practice, in analyzing pastoral activities and their determinants, and its effectiveness in a theological and pastoral sense. Interdisciplinary analyzes may focus on the evaluation of the functioning of Church institutions and organizations, pastoral initiatives, the contexts of their implementation, opportunities and barriers to implementation, being multi-faceted and based on a diagnosis of the area in which the theory is to be implemented, in a specific place and time, also taking into account theological questions and sociological regularities. It is about the postulated contribution of sociology also in the area of the implementation of theological models, imperatives and action programs, postulated, inter alia, by Piwowarski, whose need results from their rapid obsolescence. That is why he attached such importance to the constantly renewed reflections on the social and religious reality, meaning the constant cooperation among sociologists, theologians and practitioners involved in the Church's saving ministry. ${ }^{41}$

\section{Interdisciplinarity in the Course of the Research Process. The Potential of Qualitative Research}

The idea of practicing interdisciplinary research means that the cooperation among theologians and sociologists takes place at individual stages of the research process which is systemic, continuous and coherent. In pastoral theology, this concept follows the principle of comprehensive analysis, assuming a sociological and theological approach. From the perspective of sociology, it opens up fields for new issues and research questions or expands them with new aspects or dimensions. At the same time, it responds to the task of combining deductive and inductive methods described by Przygoda as part of the innovative research in pastoral theology, which is aimed at

41 Marczewski, “Wkład księdza Władysława Piwowarskiego," 370-371. 
creating models of salvific activities adequate to contemporary socio-cultural conditions, both for individual Christians and various groups of the People of God. ${ }^{42}$

Therefore, a distinguishing feature of interdisciplinary research would be the combination of methods and the compatibility of scientific activities aimed at extracting the most adequate to reality view of the truth. It should be empirically available through the analyzes of the relational and interactive dimensions of society. Such targeted exploration is the goal of pastoral theology and sociology, where cultural reality is viewed as a space for the presence and salvific activity of the Church in the world. This is important for pastoral theology, because the development of faith and religious attitudes takes place in the space of interpersonal relationships. It is subject to the influence of socialization processes in primary groups, influences secondary groups and people and communities in the Church: parishes, religious groups, peer and school communities, etc. This occurs in the context of the impact of dynamic change processes characteristic of a globalized world.

Comprehensive and up-to-date analyzes of positive experiences in the field of pastoral practice, proven models for undertaking action, as well as a quick and accurate response to the perceived symptoms of new phenomena that are of interest to pastoral theology can help in undertaking theological considerations, anticipating problems, and creating relevant pastoral programs. Therefore, this issue concerns the efficient and accurate identification of the above-mentioned phenomena, as well as formulating and specifying new research questions. In particular, it is worth emphasizing the need to ask questions and identify issues that require analysis as they arise, without undue delay beyond prudent consideration and reflection (theological discernment).

In this context, it is important to be ready to ask questions most directly related to the observed phenomena in order to test and verify the existing research tools and pastoral practices. In recognizing the research problem, knowledge about man's condition and people's attitudes towards the changing reality allows specifying issues in the direction of sublime issues that are important from the theological point of view. In this sense, the theological perspective can bring new elements to the range of issues operationalized in sociological language. The detailed research questions of sociologists are, in turn, complemented by the knowledge of pastoralists about the factors that potentially affect a given phenomenon.

Reality analyzed from the perspective of pastoral theology is a priori recognized concerning its vertical dimension, which may make it difficult to define some research problems within interdisciplinary projects. As previously stated, the achievements of the sociology of religion come to the rescue, because the scope of its interests includes issues common to pastoral theology and related, for example, to external manifestations of an individual's religiosity, as well as issues concerning its socio-cul-

42 Przygoda, "Paradygmaty metodologiczne," 31. 
tural determinants. It can be inferred that it is possible to formulate problems that, without exceeding the possibilities of empirical tools (even if these are constructed only by pastoral theologians), will take into account their theological dimensions.

Interaction among the disciplines in question concerns the operationalization of concepts, meaning naming whatever is to be studied. The process of moving from nominal to operational definitions is of great importance in order to select the variables and indicators of the analyzed phenomena as accurately as possible. The accuracy of the obtained results depends on its proper course, and sociology has well-established experience in this field. An important element of the research project mentioned above is selecting the dimensions of the phenomenon, the complete number of dependent and independent variables, indicators and the formulation of accurate hypotheses and questions in the questionnaire or interview, meaning the issues raised in them.

The observation of theologians and their comments in the area of pastoral ministry practices may broaden the range of independent variables often used by sociologists (age, gender, education, profession, place of residence, parents' education, religious practices, or attitude toward certain issues, affiliation to a group, organization, all being important for a given study), due to the possibility of their real impact on the studied phenomena and processes. Therefore, theologians, having access to pastoral practice, bring to the above stage of research their view of potential dependencies and variables affecting the issues selected for analysis.

In the discussion on a research tool in quantitative research, its sensitivity is of great importance, assuming there are no breaches within the indicators and the predetermined scope of the planned knowledge. Creating and agreeing on the type of questionnaire or an interview should also be dialectical: sociological propositions should be confronted with theological ones and vice versa. It is important to develop the right language that corresponds to the theological perspective and competences of the respondents in a given time and place. A sociological point of view may help to avoid functioning without clearly defined meanings and working with stereotypical or slogan language taken from colloquial speech, from pastoral messages characteristic of parishes or specific religious groups that are understandable only to a small group.

When using questions from previous empirical research, time should be taken into account and the wording should be checked as being up to date, for example, due to the fact that the research is several years old, even if it concerns similar issues. When preparing the final shape of the tool, it is also necessary to have a theological overview of the scope and sequence of the questions presented for filling in the questionnaire, their importance or possible irritability for the respondent, and the replies provided for each question. Throughout the entire outlined process, the awareness of scientists from both disciplines that the tools of empirical sciences do not provide access to a religious experience as a relationship with a personal 
God, stop at the description of external manifestations of human religiosity. This transposes religious beliefs to the level of various dimensions of everyday life and religious practices, including achieved moral norms, along with the awareness that religiosity is related to mystery and transcendence, so it cannot be explained solely by social reasons. ${ }^{43}$

In the analyzed context, qualitative research procedures deserve special attention as a platform for cooperation among both sciences and for developing paths of interdisciplinary analyzes. The identified research problems are not always related to measuring the phenomenon, the need to indicate its socio-demographic conditions and statistical analyzes, or the strength of the relationship between the variables. Questions are often asked that require preliminary or in-depth exploration, conducting research in their natural context, recognizing new or difficult phenomena and processes from a personal, social or pastoral perspective, and explaining and answering the questions concerning why a given phenomenon occurs or what is the individual and social perception of the meanings people give to experienced or observed events.

The answer to this type of question often requires direct contact with a specific person, looking at reality from his or her subjective perspective. Furthermore, it strives for theoretical representativeness, meaning determining a substantive and possibly comprehensive map of the identified phenomenon, process or problem. ${ }^{44}$ Qualitative research procedures serve this purpose, in particular, the Individual in Depth Interview, biographical interviews as a kind of narrative interview (conducted within the framework of the Biographic-Narrative Interpretive Method, and the Focused Group Interview, the so-called focuses or a case study with triangulation of research techniques.

The collaboration of pastoral theologians with sociologists in the development of projects using these research methods can be a valuable and successful intellectual endeavor. The interdisciplinary process of preparing and implementing empirical research will concern identifying a pastoral problem and the specific questions it implies, determining the range and dimensions of the knowledge of interest to the interdisciplinary team, determining the depth of problems, processes or phenomena in which the course or structure must be investigated, both unknown or particularly delicate aspects of the phenomenon or experiences of people whom theologians want to get to know and whose social worlds they want to know, and indicate the places, events, organizations, and communities (case study) that should and are worth researching in a given case. The dialectical process of making decisions at particular

43 Mariański, Megatrendy, 30; idem, Religia i Kościót, 133.

44 Concerning the mentioned and other characteristics of qualitative research, cf.: Creswell, Projektowanie badan naukowych, 189-217; Flick, Projektowanie badania jakościowego; idem, Jakość w badaniach jakościowych. 
stages of the research may reveal the potential of this type of research while maintaining methodological accuracy and autonomy.

Individual in-depth interviews may be used to identify hitherto unknown problems faced by Catholics, their points of view, or ways of experiencing already known issues. Scientists recommend using qualitative interviews when it comes to a deeper understanding of problems and their location in a historical, political or social context. ${ }^{45}$ This methodology may support the process of understanding complex phenomena, initially incomprehensible to theologians and pastors, for people related to the implementation of the Church's mission and researchers themselves, whether due to their innovation or excessive complexity, which is not revealed in the common external overview.

What is particularly important, from the perspective of pastoral activities and theological reflection, is that the interview, as a tool, fosters the formulation of open questions about the meaning of the situation and motives for action. It helps in perceiving the ideas and theoretical premises that are guided and used by the interlocutors in getting to know their interpretations of events. Besides, the interviews create the possibility of a discursive agreement as to the interpretation of reality, ${ }^{46}$ which allows for the verification of observations made by researchers during the research. It should also be emphasized that the interview allows capturing the qualitative differentiation, varieties and specific features of the phenomenon.

In addition to the above-mentioned aspects, theologians may find particularly interesting interviews aimed at searching for knowledge expressed in everyday language. They also seek to obtain multi-colored descriptions of the religious and moral world of Catholics, their perception of their presence in the life of the Church concerning the culture in which they live, including the conditions that affect their religious life and their perception of the world. ${ }^{47}$ Each of the above-mentioned examples of issues opens up a wide range of issues for research carried out for pastoral theology. Learning about them can significantly enrich the process of synthesis of pastoral theory and practice. The individual, in-depth interviews, oriented in this direction, will particularly help in understanding the course of various processes related to experiencing the faith, dealing with difficulties or crises in the context of faith, and the issues of religiosity in specific socio-cultural conditions. Face to face meetings as part of individual in-depth interviews are also conducive to taking up delicate or even sensitive topics, searching for the key aspects and dimensions of phenomena from the perspective of the person experiencing them.

Biographical interviews, by definition, focused on the narrative story of the respondent, her or his way of experiencing and presenting their life history or a frag-

45 Rubin -Rubin, “Jak zmierzać do celu," 210-211.

46 Hopf, "Qualitative Interviews," 350.

47 Kvale, Prowadzenie wywiadów, 316-320. 
ment. These will present their substantive value in the context of learning about the stages and ways in which people experience any kind of episode. For example, it can be related to the development of faith, a conversion or departure from religious practices, many years of living everyday life from the perspective of faith, including suffering and traumatic experiences, doing tasks for the Church or the world, with specific experiences and events and their consequences in one's life. Biographical interviews are aimed at obtaining "a comprehensive, highly indexable biographical story, developed by the storyteller himself, with minimal interference from the researcher (...). The analysis of the interviews is to make it possible to understand subjectivity in a historical situation and to describe the course of historical events as they are experienced by the subject." 48

As Kaja Kaźmierska emphasizes, the use of narrative biographical interviews, treated as a scientific activity, presupposes the awareness of procedures related to the acquisition, development and methods of analyzing research materials. ${ }^{49}$ Knowledge acquired in this way can, for pastoral theology, comprise a valuable source of observations on past events and draw a trajectory of man's future, the ways it will be experienced and finding meaning in the individual events, behavior and attitudes of people and institutions, etc., in the context of the issues researched by theologians. This type of knowledge, referring to the past, may become a valuable point of reference in the future, especially in the process of planning pastoral activities, including avoiding mistakes or duplicating repetitive patterns that are distant from the present.

Focus research, consisting in organizing discussions in small groups of people with similar characteristics in relation to the subject of the research will prove useful in learning about the beliefs, opinions and awareness of members of various pastoral groups, communities, parish councils, members of religious organizations, as well as school catechesis participants, religious events, retreats, new processes taking place in specific age or social groups, etc. Focus research allows learning about the complete range of behaviors and attitudes in relation to a given issue, problem, phenomenon, experience and their cultural and social context.

The research value of such a focus is related to the use of group dynamics, meaning interaction during the meeting, the process of specifying views but also modifying them in the context of listening to other people's statements, the naturalness of the situation of several people meeting and talking about a previously planned topic known to the interlocutors and uniting them as a community. Meeting in a homogeneous focus group enables quick integration and openness among the respondents,

48 Mrozowicki - Li-chuan, "Biograficzno-narracyjna metoda," 43-44.

49 From the perspective of projects completed in pastoral theology, the following reports are important: Kaźmierska, "Wstęp," 9-16; Schütze, "Analiza biograficzna," 141-278; Rosenthal, "Badania biograficzne," 279-307; Wengraf, "Interpretacja historii," 351-362; Przegląd Socjologii Jakościowej 9/4 (2013) [Metoda biograficzna w naukach społecznych]. 
allowing researchers to relatively deeply explore the emotional level of the interlocutors, getting to the emotions that are hidden behind the behaviors and voiced opinions. A valuable feature of such research is the ability to activate creativity, the process of generating ideas, solutions, improvements and, finally, a relatively high level of clarity and comprehensibility of the results, which in the context of interdisciplinary research is also important. ${ }^{50}$

A case study can be used, for example, as a tool for analyzing proven actions, so-called good practices or for evaluating the functioning of institutions, religious organizations, organizational models or administrative activities, evangelistic and charitable initiatives, etc. Thanks to the triangulation of research techniques, consisting in the use of several different methods of examining the analyzed case, the obtained knowledge is multifaceted, comprehensive and verified. The case study uses participant observation (the researcher goes out into the field and keeps field notes), the analyzes of documents, archival data, websites, statutes, reports, qualitative, individual, structured and free interviews, but also spontaneous, and if justifiable, also focus research, and physical artifacts are also analyzed. ${ }^{51}$

According to the definition, "a case study is an empirical study that explores a contemporary phenomenon ('case') in the context of reality, especially when the boundaries between the phenomenon and context are not entirely obvious. [...] The case study concerns a technically recognizable situation in which there are many more variables of interest to the researcher than data points, and therefore, one draws evidence from many sources and confirms the convergence of data using the triangulation method, and when collecting and analyzing data, refers to previously formulated theoretical assumptions." ${ }^{52}$ At the center of the method are the individual features of a case, which can be a person, organization, institution, organizational culture, social environment, social movement, etc.

The procedure for analyzing the results of qualitative research is complex and multi-layered, requiring high research competence and methodological precision. Due to the narrative nature of reporting conclusions, the possibility of referring to source materials, by quoting statements, including field notes in the report, etc., it can be assumed that the results of qualitative research constitute pleasant material for theological analyzes and interpretations. The advantage of interdisciplinary projects using qualitative methodology is also that the theological analysis of data can be carried out simultaneously using the procedures of sociological analysis.

\footnotetext{
50 Nicińska, "Indywidualne wywiady pogłębione," 44-48; Barbour, Badania fokusowe, 63-148.

51 Pawłowska, "Studium przypadku," 268-269; Jemielniak, Metody badań jakościowych, 2-11, 17-32.

52 Yin, Studium przypadku.
} 


\section{Summary}

The interdisciplinary nature of research carried out within pastoral theology means combining research methods and the cooperation of scientists from both disciplines in the process of planning, implementing and interpreting the results of the obtained empirical data by the researchers inspired by the problem that requires exploration in pastoral theology. In the research process, pastoral theology uses methods and techniques taken from the social sciences, but combines them with the methods used in pastoral theology. In the paradigm defined by the scheme: "see, evaluate, act," sociologists cooperate with theologians on the first level, they can also participate in the third stage by discussing social aspects as well as the opportunities and weaknesses of the proposed pastoral solutions in terms of their horizontal application. In the practical syllogism, the sociological workshop is used within the minor premise.

Interdisciplinary research should be seen as the creation of research teams in which scientists representing both disciplines, aware of the undertaken topics and possible areas of cooperation, focus on analyzing a specific fragment of reality and specific, previously identified issues. Such an approach makes the process of reflection on the adequacy and meaningfulness of interdisciplinary research more specific and, in addition to justifications and meta-subject premises, makes it possible to work out the issue and then re-evaluate and describe it at the meta-subject level.

Among the important elements that justify the cooperation of the disciplines discussed in the text, there is the time factor and the need to react quickly to circumstances. This achieves the Church's saving mission concerning people living in a given historical moment and within it, those who are pursuing their path to salvation. Related to this is the need for research as close to social reality as possible, organized every time in a comprehensive, methodologically consistent way, which concerns the process of planning, data acquisition, analysis and interpretation, and its further use by pastoral theology. The stage of interpreting the results particularly means reading them and accepting the information contained therein in the form in which they were obtained and developed, meaning recording the knowledge contained in the reports in a comprehensive way, which meets the ethical condition for scientific research. The theological, essentially autonomous interpretation, referring to the methodology of pastoral theology will then be adequate to its assumptions, falling within the criterion of seeking the truth and being authoritative for reflecting on the level of its practice.

One should also articulate the postulate of reliable, mutual knowledge of the paradigms and problem areas of individual sciences, because it favors the correct planning of research, understanding its individual stages and the rules included in them. The awareness of the scope of research fields, methods used in each discipline, 
methodological possibilities and limitations is a necessary condition for the relevant conceptualization and implementation of empirical research postulated by pastoral theologians defined as theological and sociological. It results in an adequate theological interpretation of the results of cultural research when these are carried out entirely by sociologists.

If the starting point of the research project is pastoral theology, an analysis containing all the elements of theological reflection is indispensable in order to maintain its specificity, autonomy and theological identity. Thus, the formulated indications remain in the theological sphere without weakening the message, for example, through language. This is where the risk of including secular sciences in interdisciplinary projects appears. It consists in the possibility of weakening the theological message, either through language (with an excessive desire to adapt it to the language of so-called "modern man," threatening to desacralize it with infantilism), or due to it excessive placement in a horizontal perspective, regardless of its individual or social character. An integral understanding of man is one thing, which also takes into account his social world and culture, but another thing is the theological interpretation of his existence and directing a kerygmatic message to him, in a transcendent perspective that assumes the action of God's grace. In the context of pastoral theology, the synthesis and compatibility of these two planes is a priority, which confirms the great importance of professionalism in the dialogue with empiricism and the discipline's identity.

Interdisciplinarity with sociology participating in it meets the requirements of sensitivity to the signs of the times, updates theological reflection by focusing it on the phenomena identified as "here and now," and favors the anticipation of problems through the discussion of preliminary observations of ad intra (from the Church) and ad extra (from the world) phenomena. An interdisciplinary perspective can help theologians to design pastoral solutions. Interdisciplinary research can also be used as a tool for evaluating pastoral activities by researching pastoral structures or practices, identifying issues related to new forms of communication and evangelization on the Internet, the communicativeness of language, meaning whether it is preaching or communication within the Church as a community and institution. This enables us to perceive stereotypes functioning in the awareness of the faithful or the clergy, but also opens new areas of research questions. It is an interdisciplinary proposal, which determines sociology's service character, and also means respect for the specific fields of interpretation of theology and sociology and their hermeneutic workshops. However, it may result in the extension of both the explored issues and methodological solutions within each of the sciences while maintaining their autonomy. 


\section{Bibliography}

Barbour, B., Badania fokusowe [Focuses Research] (trans. B. Komorowska) (Warszawa: Wydawnictwo Naukowe PWN 2011).

Blumer, H., Interakcjonizm symboliczny. Perspektywa i metoda [Symbolic Interactionism. Perspective and Method] (trans. G. Woroniecka) (Kraków: Nomos 2007).

Creswell, J. W., Projektowanie badań naukowych. Metody jakościowe, ilościowe i mieszane [Designing Scientific Research. Qualitative, Quantitative and Mixed Methods] (Kraków: Wydawnictwo UJ 2013).

Flick, U., Jakość w badaniach jakościowych [Quality in Qualitative Research] (trans. P. Tomanek) (Warszawa: Wydawnictwo Naukowe PWN 2011).

Flick, U., Projektowanie badania jakościowego [Designing a Qualitative Study] (trans. P. Tomanek) (Warszawa: Wydawnictwo Naukowe PWN 2010).

Först, J., Empirische Religionsforschung und die Frage nach Gott. Eine theologische Methodologie der Rezeption religionsbezogener Daten [Empirical Religious Research and the Question of God. A Theological Methodology for the Reception of Religion-Related Data] (Berlin: LIT 2010).

Giddens, A., Socjologia [Sociology] (Warszawa: Wydawnictwo Naukowe PWN 2004).

Greinacher, N., “Teologia praktyczna jako krytyczna teoria praktyki Kościoła w społeczeństwie [Practical Theology as a Critical Theory of Church Practice in Society]," Collectana Theologica 61 (1991) 55-72.

Haslinger, H., Pastoraltheologie [Pastoral Theology] (Paderborn: Schöningh 2015).

Haslinger, H., "Die wissenschaftstheoretische Frage nach der Praxis," Handbuch Praktische Theologie. I. Grundlegungen (eds. H. Haslinger et al.) (Mainz: Grünewald 1999) 102-122.

Hopf, Ch., "Qualitative Interviews - ein Überblick," Qualitative Forschung. Ein Handbuch (eds. U. Flick - E. von Kardorff - I. Steinke) (Hamburg: Rowohlt 2009) 349-360.

Hughes, P., "Theology and Social Sciences in Ministry Research," Journal of Contemporary Ministry 3 (2017) 37-57.

Jabłoński, A., "Od filozofii społecznej do socjologii filozoficznej," 100 lat Socjologii w Katolickim Uniwersytecie Lubelskim Jana Pawła II. Idee - teorie - badania ["From Social Philosophy to Philosophical Sociology, " 100 Years of Sociology at the John Paul II Catholic University of Lublin. Ideas - Theories - Research] (eds. W. Szymczak) (Lublin: Towarzystwo Naukowe KUL 2018) 21-44.

Jemielniak, D., Badania jakościowe. II. Metody i narzędzia [Qualitative Research. Methods and Tools] (Warszawa: Wydawnictwo Naukowe PWN 2012).

John Paul II, Encyclical Redemptor Hominis (1979) http://www.vatican.va/content/john-paulii/en/encyclicals/documents/hf_jp-ii_enc_04031979_redemptor-hominis.html [access: 29.10.2020].

John Paul II, Post-Synodal Apostolic Exhortation Pastores Dabo Vobis (1992), http://www.vatican.va/content/john-paul-ii/en/apost_exhortations/documents/hf_jp-ii_exh_25031992_ pastores-dabo-vobis.html [access: 29.09.2020].

Kamiński, R., "Normatywny i praktyczny wymiar refleksji teologicznopastoralnej [The Normative and Practical Dimension of Theological and Pastoral Reflection]," Roczniki Pastoralno-Katechetyczne 58 (2001) 321-332. 
Kamiński, R., “Teologia pastoralna," Leksykon teologii pastoralnej ["Pastoral Theology,” Lexicon of Pastoral Theology] (eds. R. Kamiński - W. Przygoda - M. Fiałkowski) (Lublin: Towarzystwo Naukowe KUL 2006) 838-847.

Kamiński, R., "Teologia pastoralna. Istota i zadania [Pastoral Theology. Essence and Assignments]," Studia Pastoralne 1 (2005) 9-20.

Kamiński, R., Wprowadzenie do teologii pastoralnej [Introduction to Pastoral Theology] (Kraków: Wydawnictwo M 2001).

Kaźmierska, K., "Wstęp," Metoda biograficzna w socjologii. Antologia tekstów ["Introduction," Biographical Method in Sociology. Anthology of Texts] (ed. K. Kaźmierska) (Kraków: Nomos 2012) 9-16.

Kvale, S., Prowadzenie wywiadów [Conducting Interviews] (trans. A. Dziuban) (Warszawa: Wydawnictwo Naukowe PWN 2010).

Laumer, A., Pastoraltheologie. Eine Einführung in ihre Grundlagen [Pastoral Theology. An Introduction to its Basics] (Regensburg: Pustet 2015).

Libiszowska-Żółtkowska, M., "Przedmowa," Megatrendy religijne w społeczeństwach ponowoczesnych. Studium socjologiczne ["Introduction," Religious Megatrends in Postmodern Societies. Sociological Study] (ed. J. Mariański) (Toruń: Marszałek 2016) 9-18.

Marczewski, M., "Wkład księdza Władysława Piwowarskiego do polskiej teologii pastoralnej [Fr. Władysław Piwowarski’s Contribution to Polish Pastoral Theology]," Kieleckie Studia Teologiczne 2 (2003) 366-372.

Mariański, J., Megatrendy religijne w społeczeństwach ponowoczesnych. Studium socjologiczne [Religious Megatrends in Postmodern Societies. A Sociological Study] (Toruń: Marszałek 2016).

Mariański, J., Religia i Kościół między tradycja i ponowoczesnością. Studium socjologiczne [Religion and the Church between Tradition and Post-modernity. A Sociological Study] (Kraków: Nomos 1997).

Mariański, J., Sekularyzacja, desekularyzacja, nowa duchowość. Studium socjologiczne [Secularization, Desecularization, New Spirituality. A Sociological Study] (Kraków: Nomos 2013).

Międzynarodowa Komisja Teologiczna, Teologia dzisiaj. Perspektywy, zasady i kryteria [International Theological Commission, Theology Today. Perspectives, Principles and Criteria] (Kraków: Dehon 2012).

Mikołajec, J., "Problem metody teologii pastoralnej [The Problem of the Method of Pastoral Theology]," Studia Pastoralne 1 (2005) 21-34.

Mrozowicki, A. - Li-chuan, L., "Biograficzno-narracyjna metoda interpretacyjna [The Biographic-Narrative Interpretive Method, BNIM]," Słownik socjologii jakościowej [Dictionary of Qualitative Sociology] (eds. K.T. Koncecki - P. Chomczyński) (Warszawa: Difin 2012) 43-45.

Nicińska, M., "Indywidualne wywiady pogłębione i zogniskowane wywiady grupowe - analiza porównawcza [Individual in-depth Interviews and Focus Group Interviews. A Comparative Analysis]," ASK. Społeczeństwo, badania, metody 8 (2000) 39-50.

Pawłowska, B., "Studium przypadku (Case study)," Słownik socjologii jakościowej [Dictionary of Qualitative Sociology] (eds. K.T. Koncecki - P. Chomczyński) (Warszawa: Difin 2012) 268-272.

Piotrowski, A., Ład interakcji. Studia z socjologii interpretatywnej [Order of Interaction. Studies in Interpretative Sociology] (Łódź: Wydawnictwo Uniwersytetu Łódzkiego 1998). 


\section{WIOLETTA SZYMCZAK}

Piwowarski, W., "Eklezjologiczna koncepcja teologii pastoralnej [The Ecclesiological Concept of Pastoral Theology]," Ateneum Kapłańskie 346 (1966) 300-309.

Piwowarski, W., "Perspektywa teologiczna a perspektywa socjologiczna w duszpasterstwie [The Theological Perspective and the Sociological Perspective in Pastoral Ministry]," Chrześcijanin w Świecie 26 (1973) 27-35.

Prüfer, P., "Czy nauka społeczna jest wychowawcza? Za i przeciw 'pedagogizacji' socjologii [Is Social Studies Educational? For and Against the "Pedagogization" of Sociology]," Lubelski Rocznik Pedagogiczny 35/1 (2016) 25-39.

Przegląd Socjologii Jakościowej 9/4 (2013) [Metoda biograficzna w naukach społecznych].

Przygoda, W., "Model pastoralny," Leksykon teologii pastoralnej ["Pastoral Model," Lexicon of Pastoral Theology] (eds. R. Kamiński - W. Przygoda - M. Fiałkowski) (Lublin: TN KUL 2006) 515-517.

Przygoda, W., "Paradygmaty metodologiczne we współczesnej teologii pastoralnej [Methodological Paradigms in Contemporary Pastoral Theology]," Teologia Praktyczna 10 (2009) 31-43.

Rosenthal, G., "Badania biograficzne," Metoda biograficzna w socjologii. Antologia tekstów ["Biographical Research," Biographical Method in Sociology. Anthology of Texts] (ed. K. Kaźmierska) (Kraków: Nomos 2012) 279-307.

Rubin, H.J. - Rubin, I.S., "Jak zmierzać do celu nie wiążąc sobie rąk. Projektowanie wywiadów jakościowych," Ewaluacja w edukacji ["How to Achieve a Goal Without Binding Your Hands. Designing Qualitative Interviews," Evaluation in Education] (ed. L. Korporowicz) (Warszawa: Oficyna Naukowa 1997) 201-222.

Schütze, F., "Analiza biograficzna ugruntowana empirycznie w autobiograficznym wywiadzie narracyjnym. Jak analizować autobiograficzne wywiady narracyjne," Metoda biograficzna w socjologii. Antologia tekstów ["A Biographical Analysis Empirically Based on an Autobiographical Narrative Interview. How to Analyze Autobiographical Narrative Interviews," The Biographical Method in Sociology. Anthology of Texts] (ed. K. Kaźmierska) (Kraków: Nomos 2012) 141-278.

Sztompka, P., Socjologia. Analiza społeczeństwa [Sociology. An Analysis of Society] (Kraków: Znak 2012).

Szymczak, W., "Znaki czasu," Leksykon socjologii religii. Zjawiska, badania, teorie ["Signs of Times," Lexicon of Sociology of Religion. Phenomena, Research, Theories] (Warszawa: Verbinum 2004) 467-469.

Wengraf, T., "Interpretacja historii życiowych, sytuacji życiowych i doświadczeń osobistych: biograficzno-narracyjna metoda interpretacyjna (BNIM-Biographical-Narrative Interpretative Method)," Metoda biograficzna w socjologii. Antologia tekstów ["Interpreting Life Stories, Life Situations and Personal Experiences: (BNIM: Biographical-Narrative Interpretative Method)," The Biographical Method in Sociology. Anthology of Texts] (ed. K. Kaźmierska) (Kraków: Nomos 2012) 351-362.

Wielebski, T. - Tutak, M., "Meandry interdyscyplinarności teologii pastoralnej. Przyczynek do dyskusji [Meanders of the Interdisciplinarity of Pastoral Theology. A Contribution to the Discussion]," Teologia Praktyczna 17 (2016) 25-46.

Yin, R.K., Studium przypadku w badaniach naukowych. Projektowanie i metody [A Case Study in Scientific Research. Design and Methods] (trans. J. Gilewicz) (Kraków: Wydawnictwo UJ 2015). 
Ziółkowski, M., Znaczenie, interakcja, rozumienie. Studium z symbolicznego interakcjonizmu i socjologii fenomenologicznej jako wersji socjologii humanistycznej [Meaning, Interaction, Understanding. A Study of Symbolic Interactionism and Phenomenological Sociology as a Version of Humanistic Sociology] (Warszawa: PWN 1981).

Zuhlener, P.M., Pastoraltheologie. I. Fundamental-Pastoral. Kirche zwischen Auftrag und Erwartung (Düsseldorf: Patmos 1989). 
